\title{
President Election and Dividen Policy in Indonesia
}

\author{
Fitriana Hanif ${ }^{1, *}$, Robert Andreago ${ }^{1}$, Aldi Andalas ${ }^{1}$, Pratiwi Azizah $^{1}$, Tri Prasetyo ${ }^{1}$ \\ ${ }^{1}$ Management Department, Faculty of Economics, Semarang State University, Indonesia \\ ${ }^{*}$ Corresponding author. Email: fabdulhanif81@students.unnes.ac.id
}

\begin{abstract}
This paper discusses the impact of the presidential election in Indonesia on company dividend payment policies. The presidential election years 2009, 2014, and 2019 were taken to examine their effects on dividend policy. The data used is taken from the IDX (Indonesia Stock Exchange) with the period 2009-2019. The sample used was 23 registered companies. The sample selection method using purposive sampling technique. The data analysis method used is multiple linear regression and by using a dummy variable model. This study uses firm size, EPS and leverage as control variables. By using the three presidential elections in Indonesia, this study looks at dividend policies implemented by companies in the presidential election year with the year without a presidential election. The results prove that the presidential election in Indonesia affects dividend policy positively but not significantly.
\end{abstract}

Keywords: Dividend Policy, Political Uncertainty, Presidential Election, Information Asymmetry

\section{INTRODUCTION}

Political uncertainty is an uncertain political situation, due to changes in political policies made by the government. Previous research has explained that political uncertainty occurs when economic conditions are weak, then the government or state leaders respond by making policy changes or creating a new policy. Political uncertainty creates various economic shocks seen with lower stock prices, higher return volatility, and greater systematic risk [21].

General elections are a routine agenda carried out in countries that have a presidential government system. Then the president is elected by the people. Most countries use general elections as a means of electing a country's leader. General elections are one of the state's activities that have become the center of attention both before and after the election. General elections in Indonesia may be complex elections. Indonesia is an archipelagic country and has various races, ethnicities and religions. In addition, Indonesia also has problem areas that must be resolved such as unemployment, poverty, inequality, etc. So that whoever the presidential candidate needs to think hard to be able to plan a policy that can answer the existing problems. The policies made by each presidential candidate may be different from the previous president. Changes in policies in a government cause political uncertainty in Indonesia. So that in this paper we will use the presidential election as a proxy for political uncertainty [12].
The presidential election causes political uncertainty. So that a special strategy is needed from the manager to allocate the flow of company funds. Managers who do not pay attention to political instability during general elections tend to experience a decline in company growth during and after the election period [8]. There are two ways that company management can do to overcome political instability, namely by increasing the percentage of dividend payments to investors or implementing a share buyback policy (BuyBack).

Dividend policy is a policy regarding what percentage of profits a company receives to be paid into dividends to investors [25]. Keywords: Dividend Policy; Political Uncertainty; Presidential Election; Information Asymmetry 2 Based on the opinion of Baker and Powell [4] that "company managers in Indonesia see that the dividend policy that is made affects the value of the company in the future". Which means that dividend distribution can be a positive signal for investors regarding the company's future prospects [23]. On the other hand, share buyback is considered not to affect the market [18]. The buyback of shares by company management is considered only as a tool to balance the company's finances (cash flow) in times of uncertainty, and does not have a commitment to provide satisfaction to investors in the future [12]. So that in this study the dividend variable will be used to see the behavior of company management during the presidential election. 
In looking at the effect of political uncertainty on dividend policy, this paper uses the firm size as the control variable in this study. Firm Size is considered to affect dividend policy. Investors who have a lot of capital prefer to invest in large companies, so that it is easier for large companies to be able to obtain larger funds from the capital market. Large companies have the ability to pay dividends and choose to pay dividends. Meanwhile, small companies tend not to pay dividends [22].

EPS (Earnings Per Share) is income per share. The size of the EPS gives an idea of the company's ability to generate profits per share. So that a higher EPS value will attract investors and make investors retain their assets, even in times of political uncertainty. So it can be concluded that EPS has a positive effect on the company's dividend policy [28].

Leverage is the ratio between total liabilities and total assets, the greater the value of the leverage ratio approaching one, the greater the company's financial burden. Leverage can be used as a signal to investors about the company's performance. The company has high debt, is considered to have confidence in the company's performance, and has the courage to take risks. However, companies that have high ratios leverage are at risk of going bankrupt. With this uncertainty, there is a risk of reducing the ability to pay the company's obligations, so that the company needs a reserve fund, as a step to anticipate unwanted losses. Companies with high leverage tend to pay lower dividends. So that the leverage ratio has a negative effect on dividend policy [14].

Previous studies have discussed more about the influence of politics on the economy at large, especially on stock performance during general elections [26] and [6]. The purpose of this study is to focus on looking at the effects of this study. This paper is similar to [8] which discusses the effect of political uncertainty, which is a little different from previous research that looked at the effect of political uncertainty on investment. This paper tries to look at policy dividends taken by company managers during the presidential election which causes political uncertainty. This paper looks at the dividend policy carried out by company management using a percentage of dividend payments.

\section{HYPOTHESIS DEVELOPMENT}

Indonesia has various kinds of parties with political objectives different. There are many interests and separate aims of each political party. This also cannot be separated from the different classifications of Indonesian society, starting from differences in interests, workers, regions of origin, beliefs, and ethnicities. [24] argues that "Religion is still a major force in politics in Indonesia". Due to differences in political interests, usually political parties with similar goals will form a coalition by carrying a name that will be nominated in the election. The coalition between parties will form a strategy to win the general election. The strategies of each coalition of political parties may differ from one another. This can create political uncertainty that can affect the economy. According to [8] "political parties that have 3 different political objectives can influence economic growth".

If you look at the history of economic policies carried out by the president in the reform era until now, every president has its own priority in the economic sector in Indonesia, such as Gus Dur who is known as the father of national development, emphasizing economic strategy in building the national economy. Megawati succeeded in lowering inflation and interest rates, increasing economic growth and strengthening the value of the rupiah. Susilo Bambang Yudhoyono can improve the economy in general, control inflation, increase demand for domestic products, and reduce imports [13]. Jokowi at the beginning of the period prioritized infrastructure development to support the country's economy. Then in the second period, Jokowi put more emphasis on human resource development. Economic policies made by state leaders are carried out by observing the country's economic conditions and at the time of change of government, new economic policies will affect the country's macroeconomic fundamentals [12].

Basically, the aim of the company is to maximize the welfare of investors through investment, funding and dividend policies which can be seen in the stock price in the capital market [16]. However, [9] explained that during the presidential election year there was uncertainty in stock price movements, because prices on the market did not reflect all the information available on the company. This is supported by the movement of abnormal returns in the presidential elections in 2009, 2014 and 2019 [19]; [3]; [30]. [19] explained that the information about the market during the presidential election year published by the media was not in accordance with the actual market conditions. This causes investors to lack information about stock price movements, and the existing information may not be relevant so that the stock market becomes inefficient. In addition, the manager is also unable to invest, because the investment made by the manager is carried out by observing the price movements that occur. Investments made during the presidential election year will usually be politically motivated [9]. This is done by managers of private companies. The reason for private companies to invest is politically motivated, so that the company will get more information in the future, so that the company's policies will be in accordance with the policies of the new government. In contrast to BUMN, private companies do not have information and access due to a lack of assistance related to the government [27]. Limited information on private companies will tend to reduce 
their dividend payments as a precaution to anticipate any policies issued by the new government [15].

The lack of information that investors have regarding stock price movements makes investors doubtful about the outcome of the selection which might affect the company's performance. Finally, investor confidence in the company is threatened. So that there will be differences in information received by the internal company (manager) and external parties (investors) creating information asymmetries [1].

Increased risk due to uncertainty provides an impetus for dividend payment policies from investors to companies. Managers who have information about the strength of the company in facing challenges at a change of government, will pay a bigger dividend in the presidential election year using the theory of signaling [10]. Theory Signaling is a theory that was developed [23] argues that dividends can be used as a signal about the company's future prospects. [2] stated that dividend payment is important because dividend payment provides certainty about the financial position and any dividend policy taken by the company will cause its own reaction for investors. This is also supported [4] who explain that in making dividend decisions, there are several reasons that are used by company managers in Indonesia. One of the reasons is by using dividend payments to convey information about the state of the company to investors in response to changes. In addition, investors will be more confident about the future by receiving dividends than capital gains that are uncertain and have a higher risk, so that dividend payments will reduce investors' worries about uncertainty. Multinational companies in Indonesia that have large market capitalization can do this in the face of uncertainty.

H1: The presidential elections in Indonesia have a positive influence dividend payout policy of companies in Indonesia

\begin{tabular}{|c|c|}
\hline $\begin{array}{l}\text { Presidential } \\
\text { Election }\end{array}$ & $\begin{array}{l}\text { Dividend } \\
\text { Policy }\end{array}$ \\
\cline { 2 - 3 }
\end{tabular}

Figure 1. Mindset

\section{METHODS}

This study uses the quantitative research method. The data we used is secondary data. The data and samples used come from news reports on companies registered with IDX in the 2009-2019 period. In 2020 there were 677 registered companies, however the companies registered in 2009-2019 changed from year to year. Therefore, we used 23 sample companies registered during the 2009-2019 period. Our sample selection was based on purposive sampling using a composition of 8 registered government companies and 15 registered private companies. In a sample of 15 registered companies, we each took 2 sample companies to represent each of the selected sectors based on the availability of data, but companies that entered the financial sector were not included. The following is the regression model equation in this study

$$
\begin{aligned}
\text { DIV }= & \propto+\beta 1(\text { President Election } \\
& +\beta 2(\text { Size })+\beta 3(\text { EPS }) \\
& +\beta 4(\text { Laverage })+\varepsilon)
\end{aligned}
$$

\subsection{Presidential Election}

This paper uses the presidential election as a proxy for political uncertainty by Goodell and Vahamaa, [11]. To measure this uncertainty variable, we use a dummy variable whose value is 1 during the presidential election year and 0 for the year without a presidential election. [5] consider companies to have the potential to change their work strategy in the year leading up to the election, coupled with the opinion of [7] that the existence of different political objectives can affect economic growth, thus potentially experiencing uncertainty. The presidential election years used as samples are 2009, 2014, and 2019.

\subsection{Dividend Policy}

In this paper, we measure dividend policy using the dividend yield percentage. We believe that the size of the dividend payment is carried out with the aim of showing that there is a positive signal given by the company to reduce investor concerns about the possible inability of the company to maintain its performance at the time of change of government and to increase investors' little confidence in the company in overcoming unwanted results that may arise the result of election. The data we use comes from the news reports published by the company

Yield $=\frac{\text { Dividend } \text { per } \text { share Share }}{\text { Price }} \times 100 \%$

\subsection{Control Variables}

In a study, a control variable is needed which serves as a tool to determine the accuracy of the research by looking at the effect of each variable used. In this study we used several firm size variables as control variables.

Firm SIZE (Company Size) in the paper Firm Size is defined as the total assets owned by the company. The reason we use Firm Size companyas a control variable is because in previous studies it has shown that Firm Size has a positive relationship with dividend policy and is one of the main factors that determine the company's 
dividend payment policy [29]. In this paper, the firm size uses $\ln$ of total assets

$$
\text { Firm Size }=\ln (\text { Total Assets) }
$$

EPS (Earnings Per Share), is the ratio between the income generated (net income) and the number of shares outstanding[17]. According to [20], the EPS variable has a positive effect on dividend policy. In addition, previous research argues that companies that generate profits are more likely to pay higher dividends than non-profit companies.

$E P S=\ln (E P S)$
Leverage, is the use of company assets or resources with the aim of increasing company profits. According to [14], the higher the percentage value of leverage, the risk of company bankruptcy will increase and require additional costs to cover risks that may occur. So we argue that leverage will reduce the company's capacity to pay dividends. Leverage in this study uses a debt to assets ratio (DAR). The ratio of debt to assets is calculated using the formula:

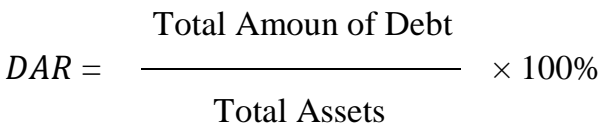

\section{RESULTS AND DISCUSSION}

Table 1. Is a descriptive statistic about the variables used to use in the analysis

\begin{tabular}{|c|c|c|c|c|c|c|c|c|c|c|}
\hline & \multicolumn{6}{|c|}{ Year of The Presidential Election } & \multicolumn{4}{|c|}{ Year Without Presidential Election } \\
\hline & $\underline{N}$ & $\underline{\text { Min }}$ & $\underline{\operatorname{Max}}$ & Mean & $\underline{\text { Std.Dev }}$ & $\underline{\mathrm{N}}$ & $\underline{\text { Min }}$ & $\underline{\operatorname{Max}}$ & Mean & $\underline{\text { Std.Dev }}$ \\
\hline Dev & 43 & 0.00 & 5.58 & 2.28 & 1.423 & 150 & 0.00 & 5.49 & 2.26 & 1.478 \\
\hline Size & 43 & 14.40 & 19.68 & 16.98 & 1.266 & 150 & 13.63 & 19.55 & 16.70 & 1.30 \\
\hline EPS & 43 & 3.24 & 7.43 & 5.36 & 1.185 & 150 & 2.25 & 8.36 & 5.39 & 1.30 \\
\hline Lev & 43 & 0.15 & 0.83 & 0.46 & 0.182 & 150 & 0.13 & 1.27 & 0.45 & 0.18 \\
\hline $\mathrm{N}$ & 43 & & & & & 150 & & & & \\
\hline
\end{tabular}

Table 1. Statistical shows descriptive of the variables used in the study. From this table, it can be seen that the average percentage of dividends paid by companies in the election years 2009, 2014 and 2019 is 2.28 and the average percentage of election years with non-election years is 0.02. Based on this table, it can be simply concluded that registered companies in Indonesia tend to pay more dividends to investors during an election year, compared to years without an election.

Table 2. Dividend Policy in election year with year without election

\begin{tabular}{llcc}
\hline & Year of The Presidential Election & Year Without Presidential Election \\
\hline Election 2009 & 2009 & 3.09 & 2.74 \\
& 2010 & & 3.56 \\
2011 & & 2.72 \\
& 2012 & 1.81 & 2.69 \\
Election 2014 & 2013 & & 1.35 \\
& 2014 & & 1.79 \\
& 2015 & & 2.40 \\
Election 2019 & 2016 & 2.292 & 1.21 \\
\hline
\end{tabular}


Table 2. Shows the average dividend payment during the election year and the year without election. From the table it can be seen that companies tend to pay more dividends

Graph 1. Percentage of Dividend Payments

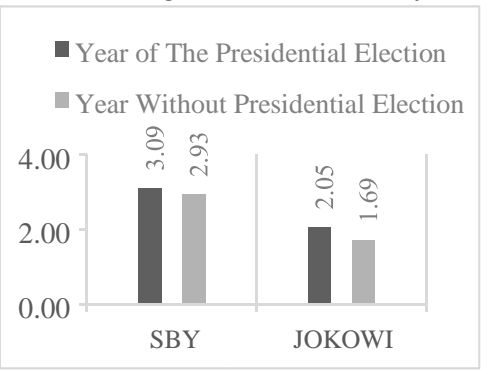

during the election year, when compared to years without elections.

Graph 1 shows the average dividend payments made by companies registered in Indonesia. The graph is based on sample data collected during the presidential election year and the presidential election year with the period 2009-2019. In this graph, it can be seen that in each presidential election year in both the SBY and Jokowi eras, dividend payments made by companies have increased when compared to years without a presidential election. Then, the graph also provides information that in the era of President SBY's leadership, the dividends paid were much higher than during the Jokowi leadership era.

Table 3. Sensitivity of Dividend Policy in Presidential Election Year

\begin{tabular}{|c|c|c|c|c|}
\hline Variable & Model 1 & Model 2 & Model 3 & Model 4 \\
\hline \multirow[t]{2}{*}{ Press Pills } & 0.018 & 0.025 & 0.060 & 0.056 \\
\hline & $(0.07)$ & $(0.101)$ & $(0.245)$ & $(0.228)$ \\
\hline \multirow[t]{2}{*}{ EPS } & & $0.289 * * *$ & $0.319 * * *$ & $0.300 * * *$ \\
\hline & & $(3,574)$ & $(3,851)$ & $(3,569)$ \\
\hline \multirow[t]{2}{*}{ Firm Size } & & & -0.127 & -0.105 \\
\hline & & & $(-1,550)$ & $(-1,250)$ \\
\hline \multirow[t]{2}{*}{ Leverage } & & & & -0.737 \\
\hline & & & & $(-1.275)$ \\
\hline$R^{2}$ & 0.00003 & 0.063 & 0.075 & 0.083 \\
\hline $\mathrm{N}$ & 193 & 193 & 193 & 193 \\
\hline
\end{tabular}

Table 3. Explain the relationship between variables divided into four models. In the first model the electoral coefficient is 0.018 , which means that it has a positive influence on dividend policy. But by looking at the $R$ square which is only 0.0000257 . Makes elections less likely to represent a dividend effect.

In the second model the electoral coefficient has a value of 0.025 , meaning that the election has a positive influence on dividend policy, the value of the EPS coefficient is 0.289 and the $\mathrm{R}$ square is 0.063015 . So, to represent the election in influencing dividends because the $\mathrm{R}$ square value of the election variable and the EPS

\section{CONCLUSION AND RECOMMENDATION}

Purpose of this paper is to examine the effect of the presidential election in Indonesia on the company's dividend policy. The presidential election causes political variable only has 0.063 or $6.30 \%$ and the rest that affects dividends are other variables. In the next model, the election has a value of 0.060 , which means that the election has a positive influence on dividend policy, EPS of 0.319 , firm size -0.127 and $R$-Square of 0.075 , from the $R$-square value it affects only $7.5 \%$ of dividend policy and the rest which affects dividends is another variable. The last model is the electoral coefficient value of 0.056 , which means that it has a positive effect on dividend policy, EPS of 0.300 , firm size of -0.105 , leverage of 0.73684 and $R$-square of 0.083 . Which means that $R$ square affects dividends through election variables, EPS, Firm Size and leverage is only $8.3 \%$.

uncertainty as a result of the asymmetry of information that causes investor confidence in the company to decrease. By using dividends, company managers inform investors about the company's ability to face the future. Based on the results obtained, all research models show 
that the dummy variable for the presidential election has a positive but insignificant effect on dividend policy in Indonesia, while leverage and firm size have a negative and insignificant effect on dividend policy.variable was Earning per share (EPS) found to have a significant positive effect on dividend policy. Our descriptive statistical results show that companies tend to respond to political uncertainty by increasing their dividend payout ratios during presidential election years.

This study has limitations. First, this study only uses three variables in seeing the effect of political uncertainty on dividends. Second, our study is still limited in the number of study sample periods because it only uses 3 election years. Third, our study only examines the effect of political uncertainty on dividends. So, for further research, you can add other control variables such as Growth, ROA, and Ownership. In addition, further research can use more company samples and a larger sample period. So that it can produce better information on future research.

\section{REFERENCES}

[1] Agung, IA, and Gede Merta. Pengaruh Profitabilitas, Likuiditas, Ukuran Perusahaan Terhadap Kebijakan Dividen Perusahaan Manu- faktur Di Bei. E-Journal of Management of Udayana University, 2014, 3 (6), 1604-1619.

[2] Agustina, C., and Ardiansari, A. Pengaruh Fak- tor Ekonomi Makro Dan Kinerja Keuangan Terhadap Nilai Perusahaan. Management Analysis Journal, 2015, 4 (1), 10-21.

[3] Alkaff, MQ. Pengaruh Pemilihan Presiden RI Tahun 2009 Terhadap Harga Saham Dan Volume Perdagangan Saham Perusahaan di Bursa Efek Indonesia (Event Study Pada Saham Anggota JII). Thesis, Department of Accounting, Faculty of Economics, "Veteran" National Development University, East Java, 2010..

[4] Baker, HK, and Powell, GE. Dividend Policy In Indonesia: Survey Evidence From Executives. Journal of Asia Business Studies, 2012, 6(1), 79-92.

[5] Baloria, VP, and Mamo, K. Policy Uncertainty and Analyst Performance. SSRN Electronic Journal, 2017.

[6] Belo, F., Gala, VD, and Li, J. Government Spending, Political Cycles, and The Cross Section of Stock Returns. Journal of Financial Economics, 2013, 107(2), 305-324.

[7] Bjørnskov, C. Does Political Ideology Affect Economic Growth? Public Choice, 2005, 123(1-2), 133-146.
[8] Durnev, A. The Real Effects of Political Uncertainty: Elections and Investment Sensitivity to Stock Prices. SSRN Electronic Journal, 2011, 514.

[9] Durnev, A., R. Morck, and B. Yeung,. Value enhancing capital budgeting and firm-specific stock return variation, Journal of Finance 59, 2004, 65105.

[10] Farooq, O., and Ahmed, N. Dividend Policy and Political Uncertainty: Evidence from The US Presidential Elections. Research in International Business and Finance, 48(January 2019), 201-209.

[11] Goodell, JW, and Vähämaa, S. US Presidential Elections and Implied Volatility: The Role of Political Uncertainty. Journal of Banking and Finance, 2013, 37(3), 1108-1117.

[12] Guay, W., and Harford, J. The Cash-Flow Permanence and Information Content of Dividend Increases Versus Repurchases. Journal of Financial Economics, 2000, 57(3), 385-415.

[13] Hakim, A., and Giovani, G. Perbandingan Perekonomian Dari Masa Soekarno Hingga Susilo Bambang Yudhoyono (1945-2009). Journal of Innovation in Business and Economics, 2012, 3(2).

[14] Jabbouri, I. Determinants of Corporate Dividend Policy in Emerging Markets: Evidence from MENA Stock Markets. Research in International Business and Finance, 2016, 37, 283-298.

[15] Lei, G., Wang, W., and Liu, M. Political Uncertainty, Dividend Policy Adjustments and Market Effects. China Journal of Accounting Studies, 2015, 3(1), 49-83.

[16] Maftukhah, I. Kepemilikan Manajerial, Kepemilikan Institusional, Dan Kinerja Keuangan Sebagai Penentu Struktur Modal Perusahaan. Journal of Management Dynamics, 2013, 4(1), 6981.

[17] Marcellyna, F., and Hartini, T. Pengaruh Earning Per Share (Eps) Terhadap Harga Saham Lq45 Di Bursa Efek Indonesia (Bei). Journal of Accounting STIE MDP, 2011, 1-7.

[18] Micheloud, G. A. How Do Investors Respond to Share Buyback Programs? Evidence from Brazil During 2008 Crisis. (Doctoral dissertation), 2013.

[19] Nailiu, B. Pengaruh Pengumuman Pencapresan Jokowi 2014 di Bursa Efek Indonesia (Event Study: Jokowi Effect pada saham LQ45). (Doctoral dissertation, Thesis S2-UAJY. Yogyakarta), 2014. 
[20] Nerviana, R. The Effect of Financial Ratios and Company Size on Dividend Policy. The Indonesian Accounting Review, 2016, 5(1), 23.

[21] Pástor, L., and Veronesi, P. Political Uncertainty and Risk Premia. Journal of Financial Economics, 2013, 110(3), 520-545.

[22] Redding, L. S. Firm Size and Dividend Payouts. Journal of financial intermediation, 1997, 6(3), 224248.

[23] Ross, SA. The Determination of Financial Structure: The Incentive Signaling Approach, 1977, 8 (1), 23-40.

[24] Tanuwidjaja, Sunny. Political Islam and Islamic Parties in Indonesia: Critically Assessing the Evidence of Islam's Political Decline. Contemporary Southeast Asia: A Journal of International and Strategic Affairs, 2010.

[25] Widhianingrum, P. Pengaruh Biaya Agensi, Kesempatan Investasi, Hutang, Likuiditas, Profitabilitas, Dan Ukuran Perusahaan Terhadap Dividend Payout Ratio. Assets: Journal of Accounting and Education, 2013, 2(1).

[26] Wolfers, J., and Zitzewitz, E. Using Markets to Inform Policy: The Case of The Iraq War. Economica, 2009, 76(302), 225-250.

[27] Yu, M., and Pan, H. The Relationship Between Politics, Institutional Environments and Private Enterprises' Access to Bank Loans. Management World, 2008, (8), 9-21. (In Chinese).

[28] Yudhanto, Stefan. Pengaruh Net Profit Margin, Return On Aset, Return On Equity, Earning Per Share Terhadap Kebijakan Dividen. Journal of Economics and Business. Faculty of Economics and Business Universitas Brawijaya, 2012, 1(2).

[29] Yusof, Y., and Ismail, S. Determinants of Dividend Policy of Public Listed Companies in Malaysia. Review Of International Business And Strategy, 2016, 26(1),. 88-99

[30] Zulfitra, Z., and Tumanggor, M. Pemilu Serentak 2019 di Indonesia Memberikan Pengaruh terhadap Likuiditas Saham Return Saham dan Harga Saham LQ45 di Bursa Efek Indonesia. Journal of Effective Economics, 2019, 2(1). 